\title{
TEACHERS' PERCEPTION IN USING TECHNOLOGICAL PEDAGOGICAL CONTENT KNOWLEDGE IN TEACHING ENGLISH AT SENIOR HIGH SCHOOLS IN BULELENG SUB-DISTRICT
}

\author{
I.W.A. WPrasetya ${ }^{1}$, I.N.A.J. Putra², I.G. Budasi ${ }^{3}$ \\ Jurusan Pendidikan Bahasa Inggris \\ UniversitasPendidikanGanesha \\ Singaraja, Indonesia \\ e-mail :andre_wira20@yahoo.com,in_adijayaputra@undiksha.ac.id,gede.budasi@undiksha.ac.id
}

\begin{abstract}
Abstrak
Penelitian ini bertujuan untuk meneliti pesepsi guru Bahasa Inggris dalam menggunakan kerangka Technological Pedagogical Content Knowledge (TPACK) dalam proses mengajar dan belajar di sekolah-sekolah menengah atas yang berada di kecamatan Buleleng. Penelitian ini menggunakan metode penelitian campuran explanatory sequential dimana menggunakan kuisioner dan interview sebagai instrumen yang telah diuji untuk validitas dan reliabilitas intrumen tersebut. Data yang berasal dari kuisioner diproses dengan menggunakan Microsoft Office Excel untuk menghitung nilai rata-rata yang bertujuan untuk mengetahui tingkatan kualifikasi dari masing-masing dimensi. Hasil dari analisis menunjukan bahwa sebagian besar guru-guru memiliki persepsi yang positif terhadap penggunaan kerangka TPACK dalam pembelejaran Bahasa Inggris di sekolah-sekolah menengah atas. Hal tersebut ditunjukan oleh posisi skor rata-rata yang berada di posisi yang tinggi dengan posisi interval skor rata-rata sebesar 139.074.
\end{abstract}

Kata Kunci: ICT, Persepsi, TPACK

\begin{abstract}
This study is aimed at investigating English teachers' perception in using Technological Pedagogical Content Knowledge (TPACK) framework in teaching and learning process at Senior High schools in Buleleng Sub District. This study applied an explanatory sequential mixed method design which used a questionnaire and interview guide as the instruments that had been tested for their validity and reliability. The data from the questionnaires were processed by using a Microsoft Office Excel to calculate the mean score in order to know the qualification level of each the dimension. The results of data analysis showed that most of the teachers had positive perceptions of using TPACK framework in teaching English at senior high schools. It was shown by the position of mean score in the high position of the interval with the mean score was 139.074.
\end{abstract}

Keywords: ICT, Perception, TPACK

\section{INTRODUCTION}

In this digital era, technology plays an important position in our environment. Every single thing such as education, communication, traveling, and business are already connected with technology. Technology is a tool that is used to help people' works. Not only adults, but children are also now very common with technology. The use of technology especially in education gives many advantages. Al Muhtadi (2013) stated that the use of technology in education especially in the classroom will give a vast impact on the overall education of students. Nowadays, teachers are demanded to have skill in using technology. Besides mastering material well, the teachers need to have knowledge about technology and how to use it to make a new variation in the instructional process. 
Formally, teachers need to master their contents of their teaching materials and how to teach it in the class. Because sometimes teachers know about the materials, but they cannot choose the appropriate way and tool to deliver it. Moreover, the technological knowledge is needed to be had by the teachers because nowadays, the role of the teachers in integrating technology becomes more focus on the education (Shulman, 1986). According to Koehler, Mishra, \& Cain (2013), there are three main components of teachers' knowledge. First is the way how a teacher teach or explain the material as we know as pedagogy. Second is the things or materials that will be delivered to students or we know as content. The third is a tool that can help teachers to teach or technology. To make a good learning process, teachers need to combine those three components in the teaching and learning process. By mixing pedagogy and content knowledge with technology, it creates technological pedagogical content knowledge (TPACK).

The technological knowledge is needed to be had by the teachers because nowadays, the role of the teachers in integrating technology becomes more focus on the education (Shulman, 1986). According to Koehler, Mishra, \& Cain (2013), there are three main components of teachers' knowledge such as pedagogy, content, and technology. To make a good learning process, teachers need to combine those three components in the teaching and learning process. By mixing pedagogy and content knowledge with technology, it creates technological pedagogical content knowledge (TPACK). That three main knowledge above, they will create the combination of PC (Pedagogy and Content), TP (Technology and Pedagogy) and TC (Technology and Content). Later those three combinations will create TPACK (Technological Pedagogical Content Knowledge).

In the process of implementing TPACK in learning process there are two possibilities that will arise, whether the teacher is able to combine these three things or vice versa. It is supported by several studies which investigate how the combination of TPACK is implemented in teaching and learning process. The studies are concern on teacher's perception in using TPACK in the learning process. Mai \& Hamzah (2016) in their study about teacher's perception in using TPACK in Malaysia shows that teachers rate themselves with a lower level in the understanding of how to combine technology and subject matter. They seem to be less confident in transforming and applying effectively their Content Knowledge in their teaching process. Otherwise according to Ohlson, Wehry, Monroe, McLemore, Maki, \& Fountain (2013) in their study about assessing in service teachers' perceptions of their TPACK development shows that teachers are very agree to use technology and combining it with content and pedagogy. Because they feel that there are many advantages that they can get by using technology in their learning process.

From statement and problem above, researcher think that it is important to conduct this study especially to find out how teachers' perception in using TPACK framework in teaching and learning process in Buleleng regency especially in teaching English at senior high schools in Buleleng sub-district. By doing this study we will know that how is the effect that is feel by the teacher in implementing technology which is combine with content and pedagogy. Later from that result we can evaluate in which part is still a problem in using technology in learning.

\section{RESEARCH METHOD}

This study was conducted at Senior High Schools in Buleleng Sub District. The subjects of this study were all of English teachers at Senior High Schools in Buleleng SubDistrict.The research design of this research was explanatory sequential mixed method, where the researcher first conducted quantitative research, analyzed the results and then built on the results to explained them in more detail with qualitative research (Creswell, 
2014). The aim of this study was to find the data about the perception of English teacher in using TPACK at Senior High School in Buleleng Sub District.

The data was obtained by using questionnaire and also interview. According to Giddings (2006), by using two kinds of instruments, it can make a research more meaningful, complete and purposeful. The questionnaire was adopted from Bostancioglu (2014)and used scale containing of 4 scales without using scale number 3 or mid-point, namely 1 (very low competency), 2 (low competency), 4 (high competency), 5 (very high competency). Scale number 3 was not used in this research because of several reasons. First, it is important for the teachers as the respondents to give their response surely such as in very low competency, low competency, high competency or very high competency. If there was scale 3 or neutral it is harder for the researcher whether they have low or high competency. It is also supported by theory from Garland (1991) on how important for the respondents to make a definite choice rather than choose neutral or intermediate positions on a scale to get an accurate response. Second, It also avoids the respondents' desires to make the interviewer happy or appear to be helpful (Garland, 1991). The questionnaire was distributed to all of English Teachers in eight senior high schools in Buleleng Sub-District.

Before the questionnaire was distributed, the questionnaire was tested by using validity and reliability test.To analyze the content validity of the questionnaire, the researcher inquired two expert judges to examine the items. The results were then analyzed by using Greogry's formula to determine the content validity as shown the following.

$$
\begin{aligned}
& =\frac{\mathrm{D}}{\text { Content Validity }}=\frac{\frac{50}{\mathrm{~A}+\mathrm{B}+\mathrm{C}+\mathrm{D}}}{} \\
& \frac{50}{0+0+0+50} \\
& =1-
\end{aligned}
$$

From the result above, the value of the content validity is 1 . It means that the level of the content validity is very high.

The questionnaire was tried out with 15 English teachers in Senior High Schools in Buleleng Sub-District. The r-table for questionnaire of teachers with total number 15 was categorized by 0.514 . After the data had been calculated, from 50 items of teachers' questionnaire, there were 15 invalid items. Because of that, there were only 35 items that were used to collect the data for English teachers' perception. The reliability was measured by Cronbach's Alpha in SPSS 16.0. The result was then compared to the level of reliability coefficient to decide whether the questionnaire reliable or not. The level of reliability coefficient can be seen in the following Table.

\section{Table 1 Ration Used in Measuring Reliability}

\begin{tabular}{cc}
\hline Reliability Coefficient & Qualification \\
\hline $0.80-1.00$ & Very High \\
\hline
\end{tabular}




\begin{tabular}{ccc}
\hline $0.60-0.80$ & High \\
$0.40-0.60$ & Average \\
$0.20-0.40$ & Low \\
$0.00-0.20$ & Very Low \\
\hline
\end{tabular}

(Adopted from Guilford in (Candiasa, 2011)

After the questionnaire was computed, the result showed that the reliability coefficient of teachers' questionnaire was 0.956 , which means that the instrument was reliable to gather data. The result can be seen in Table 2.

\section{Table 2. Reliability Statistics}

Cronbach's

Alpha Based

on

\begin{tabular}{rrr}
$\begin{array}{c}\text { Cronbach's } \\
\text { Alpha }\end{array}$ & $\begin{array}{c}\text { Standardized } \\
\text { Items }\end{array}$ & N of Items \\
.956 & .960 & 35 \\
\hline
\end{tabular}

After the data was gathered then it processed using Microsoft Office Excel to find out the mean score of each dimension. Theory from Koyan (2012) was used to find out the qualification level of each dimension. From the qualification level of each dimension, we could know that whether the teachers' response were very high, high, average, low and very low. The result of the questionnaire was transcript and analyzed based on the need of this study. The qualification level can be seen in Table 3.

Table 3: the Guidelines of Qualification Level

\begin{tabular}{ccll}
\hline No & \multicolumn{1}{c}{ Criteria } & \multicolumn{1}{c}{ Categorization } & \multicolumn{1}{c}{ Qualification } \\
\hline 1. & $\mathrm{Mi}+1.5 \mathrm{SDi} \leq \mathrm{M} \leq \mathrm{Mi}+3.0 \mathrm{SDi}$ & Very High & Very Positive \\
2. & $\mathrm{Mi}+0.5 \mathrm{SDi}<\mathrm{M}<\mathrm{Mi}+1.5 \mathrm{SDi}$ & High & Positive \\
3. & $\mathrm{Mi}-0.5 \mathrm{SDi} \leq \mathrm{M}<\mathrm{Mi}+0.5 \mathrm{SDi}$ & Average & Neutral \\
4. & $\mathrm{Mi}-1.5 \mathrm{SDi} \leq \mathrm{M}<\mathrm{Mi}-0.5 \mathrm{SDi}$ & Low & Negative \\
5. & $\mathrm{Mi}-3.0 \mathrm{SDi} \leq \mathrm{M}<\mathrm{Mi}-1.5 \mathrm{SDI}$ & Very Low & Very negative \\
\hline
\end{tabular}

(Adopted from Koyan, 2012)

The qualitative data was gained by using interview guide. There are four steps that was used. First was data collection where the researcher collected the data about teachers' perception through six questions that were taken from the questionnaire. Second was data reduction, where the collected data were selected based to the need of this study. 'R1', 'R2', 'R3', 'R4', 'R5', 'R6', 'R7', 'R8' were codes for respondent 1 to 8 . Third was data display. After the data were selected based to the need of this study, the data were displayed in order to make the researcher easier to draw conclusion about how teachers' perception by using TPACK in teaching English. Fourth was conclusion drawing and verification.In this step, the researcher drew final conclusion in order to answer the research problem. The verification was done by relating the finding with the literature review. 


\section{FINDINGS AND DISUCSSION}

There was a variety of responses between 27 English Teachers at Senior High Schools in Buleleng Sub-District. There were six dimensions from the questionnaire such as TechnologicalKnowledge, Content Knowledge, Pedagogical Content Knowledge, Technological Content Knowledge, Technological Pedagogical Knowledge, and Technological Pedagogical Content Knowledge.The result from those dimensions showed the similarities in terms of the scale number which was chosen by the respondent mostly. From the responses showed that scale number 4 (high competency) become the most chosen scales by the respondent, although the percentage number of each dimension were different.

Technological Knowledge was the first dimension which consist of 7 items. The result of the mean score calculation showed that the average of all items in Technological Knowledge dimension was 28.51.The mean was in interval $28.495 \leq \mathrm{M}<34.99$ which is in very high categorization which mean it shows to positive perception. The response of the teachers was $3.85 \%$ who chose "very low competency", $10.1 \%$ who chose "low competency", $47.7 \%$ who chose "high competency" and $38.6 \%$ who chose "very high competency". There were seven statements in the first dimension. All statements refer to the teachers' understanding about the use of a technology that can support not only for their process in teaching and learning but also in their daily life. Those statements were about whether teachers know and able to use computer, mobilephone, online dictionary, web technology 2.0 (blog, social media, wiki), miscrosoft office (microsoft word, power point, excel) or not.In other words, teachers already knew and able to use it. Based on the interview, the respondents stated that they enjoy to use technology in their teaching process and also it is very important to learn about technology, especially technology is very helpful for their teaching and learning process.

(Ya saya sangat suka ya dengan adanya teknologi yang semakin lama semakin canggih, dan saya suka belajar seperti menggunakan video bahkan membuat video. Jadi kita bersyukur sudah ada internet sebagai sumber informasi, dan saya menyaran kepada anak-anak tentang websitenya untuk belajar. $R 5 ; F$ )

"Yes I really like with the technology, and I like learn such as how to use video even making a video. So we should be grateful for the Internet as a source of information, and I suggest to the students about any websites to learn." (R5;F)

Related to the empirical study, this findings also in line with a study from Ohlson et al. (2013)which stated that it is very important to use technology in teaching process. Teachers got many information and they felt more comfortable to deliver their material by using technology.So based on the result of the questionnaire and interview guide, this study shows a positive perception from the teachers toward the use of technology in the learning process.

The second dimension was content knowledge which consists of four statements. From the calculation of all statements, the average of this dimension was 15.14. The mean score of teachers' perception on content knowledge was in the second interval which is in high categorization. The mean score was 15.14 and it was in interval $12.75 \leq \mathrm{M}<15.25$. It shows to positive perception.There were four statements in this dimension, such as teachers' competency in monitoring their writing accurately, teachers' competency to understand people speak English accurately, teachers' competency about English culture, and teachers' competency to understand the difference between spoken and written language in English.There were $56.3 \%$ from the total respondents who had high competency in content knowledge, and there were $23 \%$ from the total respondents who had very high competency 
in content knowledge. So from this finding it showed that most of the teachers as the respondents had a good competency that related to English content. It also supported by the result of the interview. The result of the interview showed that most of the interviewer able to understand English accurately.

(Bisa, karena saya juga sering berkomunikasi dengan teman-teman saya yang native speaker, $R 5 ; F)$

"Yes I can, because I often to speak with my friends who are native speaker." (R5;F)

(Kalau itu tergantung keadaan pada saat itu ya, tapi jika dimintai jawabanya atau tidak kalau ibuiya, $R 4 ; F)$

"It depends on the situation at the time, but if asked for an answer yes or no, so my answer is yes." (R4;F)

From the result of the interview, it showed that there was a close relation between content knowledge with teachers' perception of TPACK. It was in line with the empirical study by Cetin-Berber \& Erdem(2015) who stated content knowledge had the largest impact on TPACK. It also supported by Smith(2009) who found that teachers' content knowledge had a positive correlation with student learning. Because teachers' content knowledge will affect how teachers transfer a material to their students. Olfos, R., Goldrine, T., Estrella(2014)also found that teachers' content knowledge gave a significant effect for students learning and achievement of the students. The conclusion is teachers' content knowledge is in positive perception.

The third dimension was pedagogical content knowledge. This dimension discusses how understood teachers about the way they teach Englishwhich was investigated using 7 items in the questionnaire. The average of all items in this dimension was 28.88. The mean score of teachers' perception on pedagogical content knowledge was in the second interval which is in high categorization. The mean score was 28.88 and it was in interval $25.835 \leq \mathrm{M}<29.505$. It belonged to positive perception. The response of the teachers was $1.8 \%$ who chose "very low competency", 4.7\% who chose "low competency", $71 \%$ who chose "high competency" and $24 \%$ who chose "very high competency".According to SHULMAN (1986), PCK is a combination on how the teacher interprets the subject matter, finds multiple ways to represent it, and adapts the instructional materials to a concept and students' prior knowledge.

From the result of the questionnaire, $71 \%$ of the total respondents had a high competency towards pedagogical content knowledge. It means that most of the respondents able to determine learning materials, determine the right approach to teach students (i.e. communicative approach, scientific approach, Total Physical Responses), designing learning activities in accordance with the needs of the curriculum, facilitate learning activities in various ways, facilitate learning activities by creating a comfortable and friendly atmosphere for students, help the students' interaction and knowing about contextual factors that can support / inhibit the learning of English.

The finding which stated that teachers have a positive perception on pedagogical content knowledge was supported by the result of the interview. From 27 respondents, all of them stated that they used video in order to make an interesting atmosphere in the classroom and make a conducive situation. Based on their experience, it makes the students feel interested and focus on the material.

(Oww itu kita kelompokan anak-anak untuk mencari solusinya masing-masing, jadi saya kelompokan misalnya ada 30 anak saya kelompokan menjadi 6 kelompok terdiri 5 orang. $R 2: F)$ 
"So we divided the students to find the solution. I divided the students for example there are 30 students, I divided them become 6 groups which consist of 5 students." $(\mathrm{R} 2: \mathrm{F})$

Theory from Guerriero(2013), also supported these findings which stated that teacher should able to cover well pedagogical content knowledge because it involves all the required cognitive knowledge for creating effective teaching and learning environments.

The fourth dimension was technological content knowledge which was investigated using 6 items in the questionnaire. From the calculation of responses on those 6 items, the average of all items value was 23.51. This mean score was in interval $22.5 \leq \mathrm{M}<25.5$. On the other words it was in positive qualification.Most of the teachers gave their high responses in High Competency scale with value $58.2 \%$. Very High Competency with value $25.2 \%$, Low Competency with value $16.5 \%$ and there is no tecahers who chose Very Low Competency. In this fourth dimension, it discussses about how understood teachers about the combination of using technology with English content that will they tought in the class.

The finding above was supported by the interview result from all of the respondents. The researcher asked about "Which material do you feel is greatly helped by the use of technology?". Most of the respondents stated that all of the materials are greatly helped by the use of technology. But listening and speaking have a higher portion based on their opinion. Because the students can hear the real accent from the native speaker.

(Yang paling kelihatan sih listening ya kalau menurut saya karena kan kita bisa cari materi yang memang yang ngomong itu orang asli, native speaker jadi mereka bisa tau accentnya kayak gimana. $R 1: F)$

"The most obvious thing is listening, because we can find material which is the speaker is the real native speaker. So the students know how is the right accent." (R1:F)

(Yang paling mudah listening dan speaking. Di speaking yang terutuma karena mereka mudah sekali mendengar contoh percakapan. R2:F)

"The easiest are listening and speaking. Because in speaking the students can hear the example of the convertation." (R2:F)

This finding was supported by the previous study by Mundy, Kupczynski, \& Kee (2012), which also become one of literature reviews in this study. Mundy et al. (2012) stated that the result of their study was teachers had a positive perception of technology use in the schools. By using technology it helped teacher's worked either when making lesson plan which was very related with content of material until executed it in the form of teaching and learning process.

The fifth dimension was technological pedagogical knowledge. The average of all items value in technological pedagogical knowledge was 23.44. It was categorized in high categorization and positive perception. In this dimension, it discussses about how understood teachers about the combination of using technology with their teaching style in the class room.most teachers gave their high responses in High Competency scale with value $66.7 \%$. Very High Competency with value $19.8 \%$, Low Competency with value $13.8 \%$ and there is no tecahers who chose Very Low Competency.

The finding above was supported by the interview result of $R 1, R 2, R 3, R 4, R 5, R 6$ and R7. The researcher asked about "How do you involve students in solving problems that arise in the material that you teach? Especially by using technology". Those respondents stated the same anwers that they asked the students to find out the answer by googling.

(Ya yang pasti yang paling cepat sih saya suruh cobak cek di google. R1:F)

"Yes, definitely the fastest way is I told the students to check it on google." (R1:F) 
(Oh kalau itu sering, apalagi sekarang sudah bisa membawa hp. Googling misalkan mencari contoh kosa kata misalnya saya juga tidak tahu jadi siswa bisa googling. R3:M)

"Oh I often do that, especially now students can bring a mobilephone. Googling for example looking for any vocabularies. If I also do not know about that so the students can googling." (R3:M)

The use of technology also helped the teachers in designing their lesson plan. This statement also founded by the previous study in literature review. A study by Mundy et al.(2012) stated that The use of technology in the classroom gives benefit for teachers and students, such as increased motivation and achievement of the students. Teachers also stated by using technology it helps their work either when making lesson plan until executing it in the form of teaching and learning process.

A study from Ghavifekr et al. (2015) has a related line with the explanation before. Ghavifekr, Athirah, \& Rosdy (2015), stated that by using ICT in the teaching process, it could change the traditional teaching method with technology teaching method. The result of this study was by using ICT in teaching and learning process, it could create a new strategy in teaching. In addition, it also could increase students' interest.

The last dimension was the analysis of teachers' perception toward technological pedagogical content knowledge which has 5 items. The result of the mean score calculation showed that the average of this dimension was 19.55. It was categorized in high categorization and positive perception. The response of the teachers is $0 \%$ who chose "very low competency", $13.2 \%$ who chose "low competency", $69 \%$ who chose "high competency" and $17.8 \%$ who chose "very high competency".

Based on the data, respondents who have this low knowledge are respondents who are not understand well in using technology in teaching and learning process. Based on direct interview with those respondents, the fact is they know about those technology but they cannot use it especially for teaching and learning process. There are several factors that may affect it. It can be because of their age which is between 53-55 years old (from the data of the respondents) and also their desire to use it. But most of the teachers had a high competency toward this dimension with value $69 \%$. It shows teachers as the respondents here have a positive perception about the use of technology in teaching and learning process, especially in teaching and learning English as a foreign language. This data also supported by the result of the interview where the respondents say that technology is very help their activities start from making a lesson plan, explaining the materials, giving assignment even checking students' assignment.

(Yang paling sering menggunakan WhatsApp karena ibu bisa share informasi (tugas) secara langsung di group WhatsApp yang sudah dibuat oleh siswa. R4:F)

"I often use WhatsApp because I can share information (assignment) directly in WhatsApp's group which already made by students." (R4:F)

This finding also in line with the previous literature review which conducted the same topic about teachers' perception about the use of TPACK framework in the learning process. The study conducted by Sancar-Tokmak, Surmeli, \& Ozgelen (2014)and Ohlson et al. (2013)were the previous studies that investigated related topic with the present study. There are several similarities and differences of the previous study with this present study. The similarities are the result that shows teachers have a positive perception toward the use of TPACK framework in the learning process and teachers feel much helped by using technology which combines with the content of the material and teaching strategy. The differences of the previous study with this present study that makes this present study has something new are the subject of the study and the school level studied. If the previous studies the subject are biology teachers from junior high schools and also kindergarten teachers, so this present study take English teachers at senior 
high schools in Buleleng Sub-District. It shows that there is something new from this present study that can differentiate from the previous study.

In general, the English teachers at senior high schools in Buleleng sub-district had a positive perception toward the use of TPACK in teaching English at Senior High Schools in Buleleng Sub-District. It showed by the general mean score which was 139.074 which was categorized in high categorization or positive perception.

\section{CONCLUSION}

Based on the findings and discussion, the conclusion of this study was that the result of the perception of the English teachers at the senior high school in Buleleng sub-district was positive regarding the use of technological pedagogical content knowledge in teaching English. It was indicated by high qualification of the mean score that showed technological knowledge categorized in very high scale which means the perception of the teachers was very positive and for the other dimensions of TPACK categorized in high scale which mean the perception of the teachers was positive. The subject of the study makes this present study differs from the previous study. The subjects of this study are English teachers of senior high schools in Buleleng Sub-District. Whereas the similarities of this present study with the previous studies are the teachers agree and have a positive perception toward the use of TPACK framework in the learning process and teachers agree that the use of technology in the learning process is important and give many advantages for them.

\section{REFERENCES}

Al Muhtadi, M. (2013). The Impact of Technology on Education. Al-Nasser University Journal.

Bostancioglu, A. (2014). EFL-TPACK: The Development of a Questionnaire to Measure the Technology Pedagogy and Content Knowledge (TPACK) of English as Foreign Language (EFL) Teachers. EuroCALL Teacher Education SIG Workshop.

Candiasa. (2011). Pengujian Instrumen Penelitian Disertai Aplikasi ITEMAN dan BIGSTEPS. Singaraja: Undiksha Press.

Cetin-Berber, D., \& Erdem, A. (2015). An Investigation of Turkish Pre-Service Teachers' Technological, Pedagogical and Content Knowledge. Computers, 4(3), 234-250. https://doi.org/10.3390/computers4030234

Creswell, J. W. (2014). Research Design Qualitative, Quantitative, and Mixed Methods Approaches (4th ed.). United States of America: SAGE Publications.

Garland, R. (1991). The Mid-Point on a Rating Scale : Is it Desirable? Marketing Bulletin, (2), $66-70$.

Ghavifekr, S., Athirah, W., \& Rosdy, W. (2015). Teaching and Learning with Technology: Effectiveness of ICT Integration in Schools. International Journal of Research in Education and Science (IJRES), 1(2), 175-191.

Giddings, L. S. (2006). Mixed-methods research. Journal of Research in Nursing, 11(3), 195-203. https://doi.org/10.1177/1744987106064635 
Guerriero, S. (2013). Teachers' Pedagogical Knowledge and the Teaching Profession: Background Report and Project Objectives. Better Policies for Better Lives, 1-7. Retrieved from http://www.oecd.org/edu/ceri/Background_document_to_Symposium_ITEL-FINAL.pdf

Koehler, M. J., Mishra, P., \& Cain, W. (2013). What Is Technological Pedagogical Content Knowledge ( TPACK )? Journal of Education, 193(13), 13-19.

Koyan, I. W. (2012). Statistik pendidikan teknik analisis data kuantitatif. Singaraja: Undiksha Press.

Mai, M. Y., \& Hamzah, M. (2016). Primary Science Teachers ' Perceptions of Technological Pedagogical and Content Knowledge ( TPACK ) In Malaysia. European Journal of Social Sciences Education and Research, 6, 167-179.

Mundy, M. A., Kupczynski, L., \& Kee, R. (2012). Teacher's perceptions of technology use in the schools. SAGE Open, 2(1), 1-8. https://doi.org/10.1177/2158244012440813

Ohlson, T., Wehry, S., Monroe-ossi, H., Mclemore, B., Maki, K., \& Fountain, C. (2013). Assessing Inservice Teachers ' Perceptions of Their TPACK Development. University of North Florida, 2591-2596.

Olfos, R., Goldrine, T., Estrella, S. (2014). Teachers' pedagogical content knowledge and its relation with students' understanding. Revista Brasileira de Educação, 19(59), 913-944. https://doi.org/10.1590/S1413-24782014000900006

Sancar-Tokmak, H., Surmeli, H., \& Ozgelen, S. (2014). Preservice science teachers' perceptions of their TPACK development after creating digital stories. International Journal of Environmental and Science Education, 9(3), 247-264. https://doi.org/10.12973/ijese.2014.214a

SHULMAN, L. S. (1986). Those Who Understand: Knowledge Growth in Teaching. Educational Researcher, 15(2), 4-14. https://doi.org/10.3102/0013189X015002004

Smith, P. S. (2009). Exploring the relationship between teacher content knowledge and student learning. Proceedings of the NARST 2009 Annual Meeting, 1-15. 